\title{
Mine Subsidence as a Post-Mining Effect in the Upper Silesia Coal Basin
}

\author{
Grzegorz Strozik $^{1}$, Rafał Jendruś ${ }^{1,2 *}$, Anna Manowska ${ }^{1}$, Marcin Popczyk ${ }^{1}$ \\ ${ }^{1}$ Silesian University of Technology, Faculty of Mining and Geology, \\ Akademicka 2A, 44-100 Gliwice, Poland \\ ${ }^{2}$ GeoRock Geotechnical Services Company, \\ Armii Krajowej 14/I/10, 41-943 Piekary Śląskie, Poland,
}

Received: 6 November 2015

Accepted: 23 December 2015

\begin{abstract}
On the basis of three selected examples, some problems attributed to the presence of voids resulted from mining operations in already commissioned underground coal mines are discussed. Continuous and discontinuous deformations of the ground surface (sinkholes and subsidence troughs) of anthropogenic origination implicate hazards for the ground surface, even many decades after completion of mining work. Nowadays, when decommissioning and flooding of numerous mines happens, ground movements as well as seismic events related to flooding of abandoned underground mines can be observed. The first case study draws attention to the problems of effective voids localisation methods as well as the reliability of grout injection operations for road construction purposes. The second case emphasizes a problem occurring often in areas with long and complex mining histories, meaning appropriate determination of origin, process and protective measures regarding occurred ground deformations, or damage to buildings. The third case describes specific effects on the surface (shocks and ground surface elevation) generated by the flooding of decommissioned mines.
\end{abstract}

Keywords: sinkholes, subsidence, abandoned underground mines, post-mining areas

\section{Introduction}

Hundreds of years of underground mining operations in the Upper Silesia Coal Basin (USCB) has resulted in heavy degradation of the surface of the ground, which is frequently densely urbanized. Since the 1990s, though, mining activities have been strongly curtailed (in the case of hard coal mining annual production decreased from

*e-mail: Rafal.Jendrus@polsl.pl
$200 \cdot 10^{6} \mathrm{Mg}$ in 1980 to nearly $80 \cdot 10^{6} \mathrm{Mg}$ in 2012 ), and the total surface of active mining areas has been reduced by half. But the environmental impacts from the already completed mining works still generate damage.

The USCB in its Polish part has an area of $5,400 \mathrm{~km}^{2}$. The whole area includes coal beds with total capacity of round 70 billion tons, from which $10-15 \%$ have already been extracted [1]. Currently active mine areas have a total surface of $1,100 \mathrm{~km}^{2}(19 \%)$. Decommissioned mines and exhausted coal reserves represent a total surface of $635 \mathrm{~km}^{2}(11 \%)$. The next $27 \%$ of the USCB area contains coal beds at a depth below $1,000 \mathrm{~m}$, which may be considered for future mining operations. Depth of the coal beds 
is changing from 0 (outcrops) down to maximally 4,600 $\mathrm{m}$ below sea level. The USCB was rich also in other mineral beds, from which the most important were silver-zinclead ore beds located in the northern part of the region, which were the subject of the oldest mine operations in this area in the Middle Ages, due to their shallow depth (down to $100 \mathrm{~m}$ below sea level maximally). Mining of silver was completed in the beginning of the $19^{\text {th }}$ century and zinc-lead beds were depleted in the second half of the $20^{\text {th }}$ century. In some areas, shallow residues from older metal mines have been later undermined by deeper coal extraction and resulted in dramatic development of mine subsidence problems in densely populated and urbanised areas. The population of the USCB area is approaching 3.5 million people, with average density of 645 per $\mathrm{km}^{2}$.

The most important and most frequent problems of areas of completed mining operations include mine subsidence and risks to buildings, and the resulting infrastructure damage.

Results of current, mostly deep coal bed extractions frequently induce or intensify geomechanical impacts from previous shallow coal mining, and historical residues from metal ore mining or quarrying.

In the case of building safety, the problem not only results from the residual effects of mining activities (in a form of subsidence or sinkholes), but also from the properties of the grounds, which create a direct foundation for buildings. Due to the intensive mining and overall industrial activities at the USCB area, a large amount of terrain was subject to mine waste disposal. In contrast to the modern approach to the waste disposal procedures, in historical times any industrial waste was disposed of freely in the most convenient locations, mainly very close to the factories and mines, and located far from settlements at these times, but now representing vivid areas of modern cities.

As a result of these implications as well as territorial expansion of the cities, many contemporary buildings are built on areas that were not intended to be urbanised and allowed for uncontrolled storage of waste. This waste from exploration workings, mining operations, metallurgical processes, and other activities - were formerly disposed of without consideration of the future.

Nowadays, due to the territorial development of urbanised areas, the construction of roads, and overall modernisation processes, many new investments in the UCSB area must cope with problems related not only to current mining issues, but also to historic and frequently poorly documented industrial operations (much archival information was destroyed during World War II) [2].

On the basis of the three selected case studies, the problems of the late subsidence effects and their influence on the safety and functionality of building structures will be presented. Due to the complexity of problems addressed in this paper, the intent of the authors is to show how surprisingly and unexpectedly these phenomena can arise and influence local life in any aspect, including environmental protection, business, public safety, living standards, etc.

Also, decommissioning mines and the side-effects of terminating underground activities may unfavourably influence urbanised areas that expect to be free from further negative impacts of decommissioned mines.

\section{Subsidence as a Late Effect of Terminated Mines}

In the USCB, ca. $98 \%$ of coal output is produced using the longwall system with caving. Because most of the shallow deposits have already been extracted, most of the subsidence resulting from the current mining operations occur in the form of subsidence troughs (continuous subsidence). Due to high rock mass pressure at large depths, collapse of the roof strata takes place immediately after coal extraction happens, then the ground surface becomes stable in a relatively short time after completion of the mining works (most of the ground movement occurs between one and three years after completion mining) [3].

At shallow depths, however, where the pressure of the rock mass is significantly lower, voids (abandoned workings and cavings) can be present in quasi-stable conditions even many decades after mining is completed. In USCB mining-geological conditions, the minimal depth required to generate a fully developed subsidence trough after mining extraction is $200 \mathrm{~m}$; however, the most frequently observed shallow voids occur at depths of up to $80 \mathrm{~m}$. The last observation may result from the fact that heavy surface structures could reach such a depth. In the case of the loss of stability of such a void and its sudden collapse, a sinkhole subsidence (discontinuous subsidence) appears on the surface, which can cause severe damage to existing structures and create public safety issues.

The most important factors that can influence the generation of sinkholes are [4]:

- The thin layers of loose rock mass close to the surface of the ground.

- Mining in close proximity to geological faults.

- Mining in a close proximity to bed outcroppings or other geological strata.

- The high rate of advance of the mining front.

- Overlaying mining area borders.

A sinkhole may occur as a result of an underground void collapsing. However, it can happen suddenly even after many years in quasi stable conditions. Sinkholes can be generated by [5]:

- Changes of structure in the rocks surrounding a void, i.e., influence of water, fracturing, weathering, suffusion, and clogging processes, etc.

- Movement of rocks resulting from deeper, current mining operations.

- Changes in hydrogeological conditions.

- Static or dynamic load on the ground surface.

- Seismic activity (also related to mining operations).

Each collapse of voids does not necessarily result in a sinkhole. A discontinuation of firm layers of the rock mass must occur first, followed by a transfer of loose rock material toward the voids. Typical for the processes of sinkhole generation is that there are no warning symptoms before 
their occurrence - the creation of sinkholes is sudden and fast, and their dimensions are large in relation to typical buildings. Sinkholes affect surface structure heavily, but in small areal range.

Another subsidence-related issue results from the flooding of decommissioned mines, which is a relatively new phenomena being observed in the USCB area. Historically, closure of mines was unique due to the rich coal deposits and adequately long lifetimes of the mines. Even today the flooding of abandoned mines does not happen often because there is a strong need to protect operational mines against flooding. The main protective measure against the increasing water hazard in active mines is drainage of already closed mines and keeping its voids and workings empty to avoid building a water level near an active mine.

\section{Case Study I: Grouting of the Shallow Voids in the Course of a Motorway in Jaworzno}

Like railways and roadways, linear structures are especially vulnerable to ground deformations resulting from mining activities. Heavy deformations of existing roads occur regularly in areas of current mining operations, but new roadways also are endangered by current mining works (considered as expected) and, sometimes rather surprisingly, by the remnants of past or even historical mining $[6,7]$.

At a length of about $2,200 \mathrm{~m}$, the newly constructed "DP" motorway in Jaworzno was planned to run through an area of shallow coal mine extraction at a depth of from $12 \mathrm{~m}$ down to $500 \mathrm{~m}$, where the mining operations took place between 1957 and 1989. Generally, the mining works move from shallow depths to deeper parts of the rock mass, so the most shallow parts of the deposits down to $130 \mathrm{~m}$ were extracted in 1957-1969, and the last extraction took place in 1989 at a depth of $500 \mathrm{~m}$ [8].

The surface of the ground in the considered area consists of quaternary sands of 2 to $6 \mathrm{~m}$ thickness, followed by eroded carboniferous sands and gravels with sandstone aggregates to a depth of 10 to $24 \mathrm{~m}$. Below the weathered zone productive carboniferous occurs, represented by numerous coal seams interlayered with sandstone, claystone, and mudstone, which are generally heavily fractured and eroded with average compressive strength of from 0.2 to 1.0 MPa at the roof of the carboniferous complex, increasing to about $15 \mathrm{MPa}$ in deeper layers.

Because the shallow voids from earlier times have already been undermined by later mine works, the general assumption was that the area shall be safe and stabilized in terms of subsidence occurrence.

However, direct field observations in the area of prospective road construction works exhibited evidence of sinkholes in the ground (Fig. 1), which was further confirmed by advanced exploration using ground-penetrating radar (GPR) and microgravimetry methods. As a result of these measurements, it was discovered that the subsoil foundation as well as deeper strata contain significant

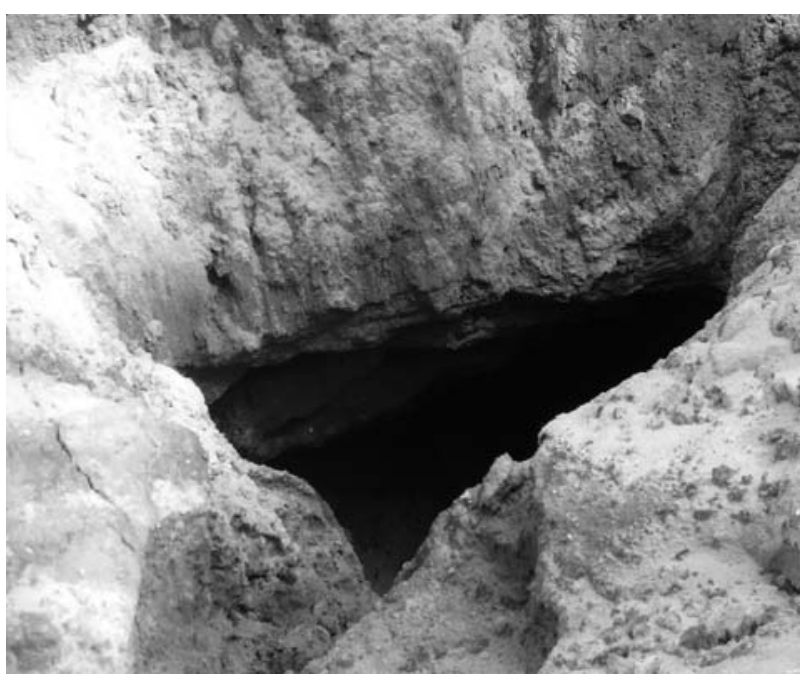

Fig. 1. Sinkhole subsidence in an area of shallow mining works at the JK mine in Jaworzno (photo: R. Jendruś).

voids and zones of lowered density, the presence of which creates a hazard for the motorway.

Grouting of the voids was implemented to repair the ground foundation and eliminate the subsidence hazard. A line of 32 boring up to $30 \mathrm{~m}$ deep was drilled with respect to geophysical measurement results [9]. The voids were filled with a mixture of a commercially available mineral binder (based on activated fly ash) and water, with the use of low-pressure injection (mostly free gravitational flow; Fig. 2).

Injection mixtures must meet both rheological criteria, regarding properties of flow and range of filling, and mechanical criteria, regarding their properties as a solid body after settling [10]. Composition of a fill mixture must also meet obligatory environmental standards.

The course of the grouting operation indicated significant differentiation between receptivity of the borings, which ranged from 106 to 2,166 $\mathrm{m}^{3}$ (except borings, which did not take any volume of grout). Volumes of grout received by all borings are shown in Fig. 3 (the minimal values are out of scale to show location of the holes and should be considered as zero).

Lack of groutability observed in a series of consecutive borings (Fig. 3) stays in contrast to the geophysical predictions about location of the most significant voids and shows clearly that the results of indirect observation methods must be considered with caution. From the other side, complex geological structures and highly variable hydrogeological conditions in the area of research make the geophysical observations unclear and increase their level of uncertainty.

Voids and loose layers have been found only in $40 \%$ of the drilled borings, which is less than the average efficiency of drillings for shallow grouting works suggested by geotechnical engineers from Poland and the USA [11, 12 ], who claim that 35 to $40 \%$ of drills do not meet voids in the geotechnical works on the areas of old shallow mining operations. 


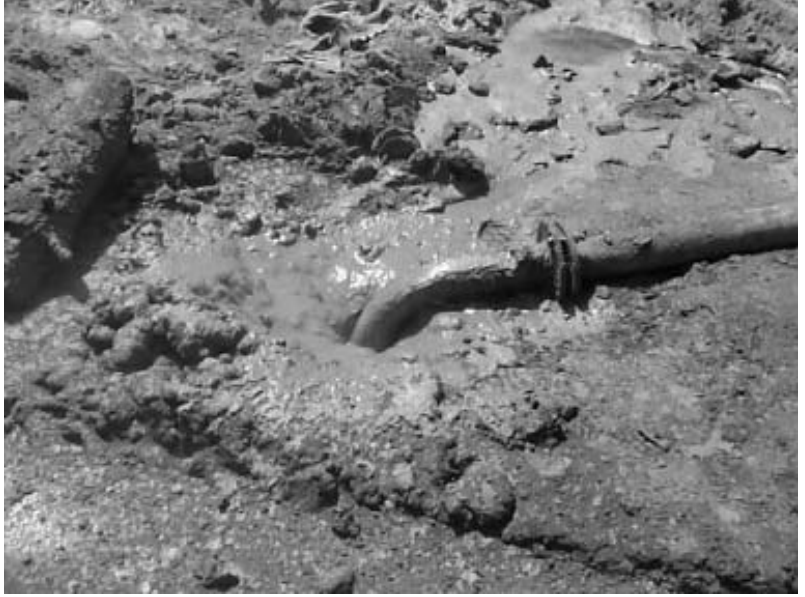

Fig. 2. Grouting works on the DP motorway construction site (photo: R. Jendruś).

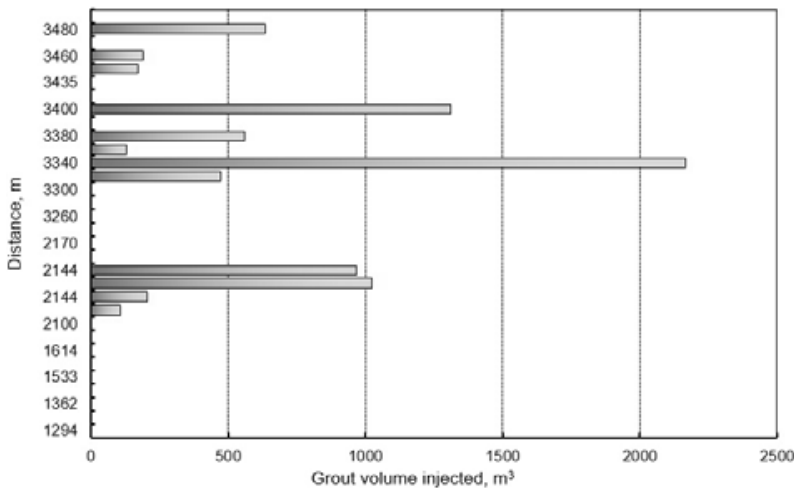

Fig. 3. Receptivity of injection holes while grouting for the DP motorway.

Much more interesting however, are the groups of tightly located borings, which achieved the highest volumes of grout injected. In the first area of intensive grout consumption, between 2,124 and 2,144 $\mathrm{m}$ and also between 3,340 and $3,480 \mathrm{~m}$ of the road, the volume of grout injected reached a value of $100 \mathrm{~m}^{3} / \mathrm{m}$ of road length. Together with the fact that two consecutive borings received round $1,000 \mathrm{~m}^{3}$ of grout each, this means that the borings are connected to a complex void system of large volume, which could potentially create significant danger to the surface structures $[8,2]$.

It should also be mentioned that due to the drill logs, the thickness of the loose soil strata was between 1.5 and $3.0 \mathrm{~m}$ ( $2.0 \mathrm{~m}$ on average) and evident voids have been noticed occasionally in the borings of the maximum grout injection volume. Generally no coincidence has been observed between dimensions of voids and loose layers observed in borings and their later receptivity of grout during the filling phase.

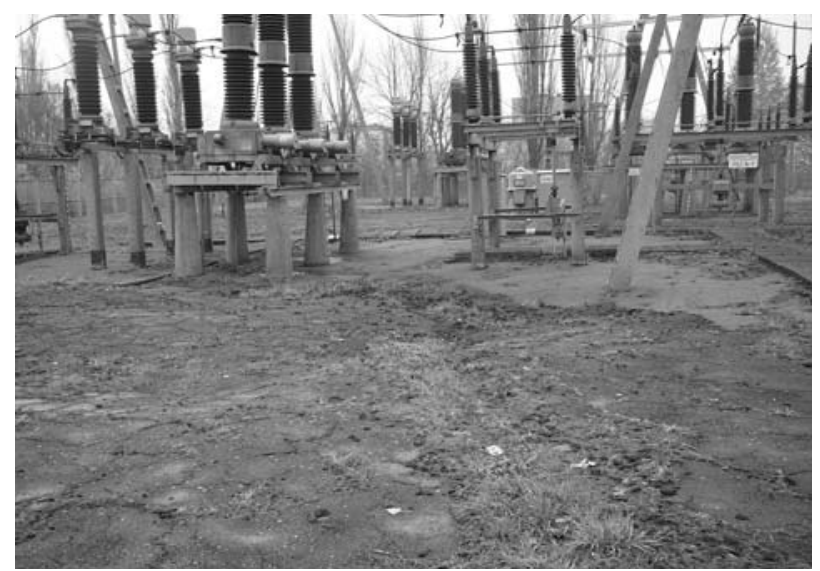

Fig. 4. Sinkholes and tilted poles at the Julian Power Distribution Centrex (photo: R. Jendruś).

\section{Case Study II: Determination of the Reasons of Subsidence at the Julian Power Distribution Centre in Piekary Slaskie}

The Julian Power Distribution Centre (PDC) in Piekary Slaskie is located in an area heavily influenced by past mining operations. Historical zinc-lead ore extraction took place at shallow depths $(0-100 \mathrm{~m})$ and the area was later undermined by intensive coal mining at depths of 180 to $500 \mathrm{~m}$.

In the geological profile of the site, quaternary sand and clays can be distinguished to a depth of about $4 \mathrm{~m}$. Below, complex Triassic formations occur down to about 150-200 m, represented by limestone and dolomites, heavily fractured and eroded by migrating ground waters (numerous caverns filled with clayey material are present). Below the roof of the Triassic rocks a large complex of Carboniferous strata occur with numerous coal seams interlaced with sandstone and shale, which were the subject of intensive mining extraction.

At the PDC plant, which was built in 1972, small sinkholes have been observed, resulting in tilting of poles of overhead high-voltage lines, couplings, and switches, which endangered the facility and jeopardized power to thousands of consumers (Fig. 4).

In an attempt to protect the PDC facilities, first of all the source of the subsidence processes have to be determined. On the basis of experience with the local mining conditions and history of mining operations, two options for the potential sources of the observed damage have been formulated for further analysis:

- The damages are induced by a current subsidence through evolution resulting from present mining works in the coal mine that operated in the area.

- The damages result from the activation of an old shallow void, as a late effect of the past metal ore mining works.

Studies of archival mine maps, however, revealed that the influence of both current and historical mining operations on the present subsidence effects at the PDC area is not probable $[13,14]$. 
In the case of zinc-lead ore mining, which took place in the area in the $19^{\text {th }}$ century, any influence of historical mining operations is unlikely, while the PDC facility is located to the north of an outcrop line of the ore body, which extends to the south (Fig. 5). A 1913 map shows already completed mining operations that took place at the outcrop area that began with the use of the opencast method and later using underground methods in the southern direction, where the ore body declines. The history of hard coal mining operations in the PDC area is much more complex. But after thorough analyses of mine maps there was no reason to point at any completed mine works as the source of sinkhole subsidence and damages to the PDC facility. A significant element of the already minedout coal seams is that all coal seams from the " 400 " group do not reach the PDC area because their outcrops create a straight W-E line some distance to the north from PDC, so the mining operations in these seams can have potentially only indirect influences (Fig. 6).

Generally the coal extraction took place under this area in 16 coal seams or slices at a depth of from 180 to 500 $\mathrm{m}$, and in the distance to the present PDC facility from 0 to $700 \mathrm{~m}$. The extraction works have been conducted from 1951 until 2003; however, most of the works were completed before 1980, and only one coal seam was mined out in 1996-2003, at a distance of at least $550 \mathrm{~m}$ from the PDC area [14].

All generated ground movements related to evolution of subsidence troughs should be quieted until the sinkholes started their activity in the PDC area. Moreover, all mining

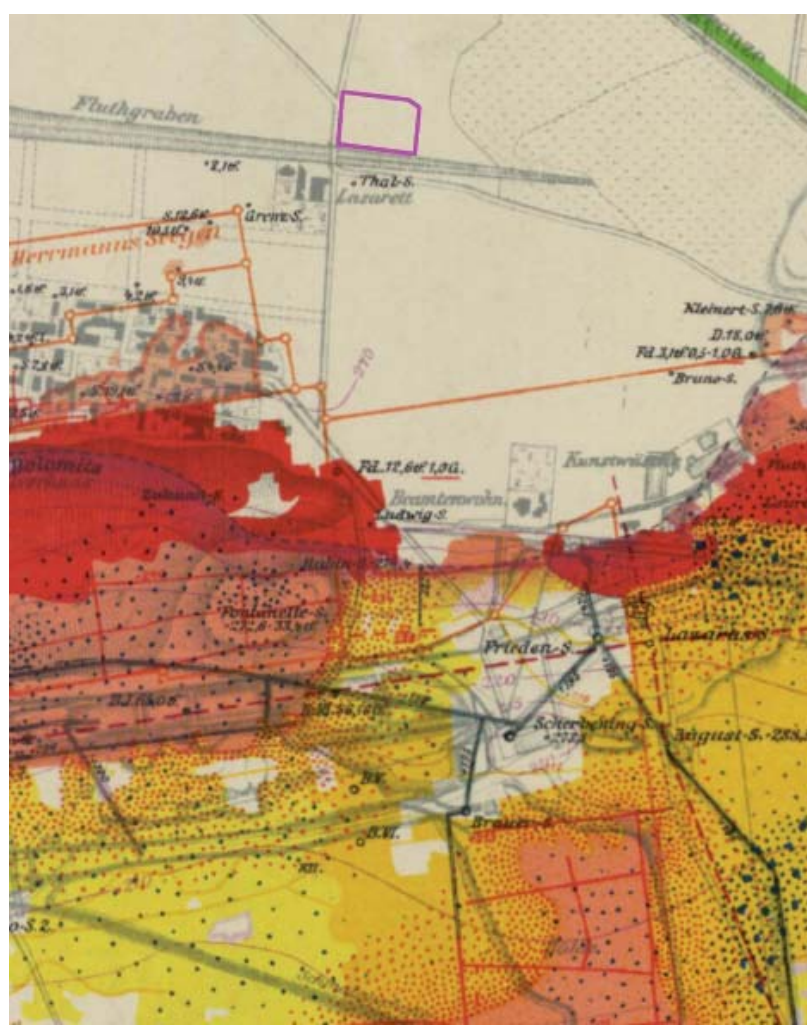

Fig. 5. Part of a 1913 map presenting zinc-lead ore mining works in the southern part of Piekary Slaskie [3].

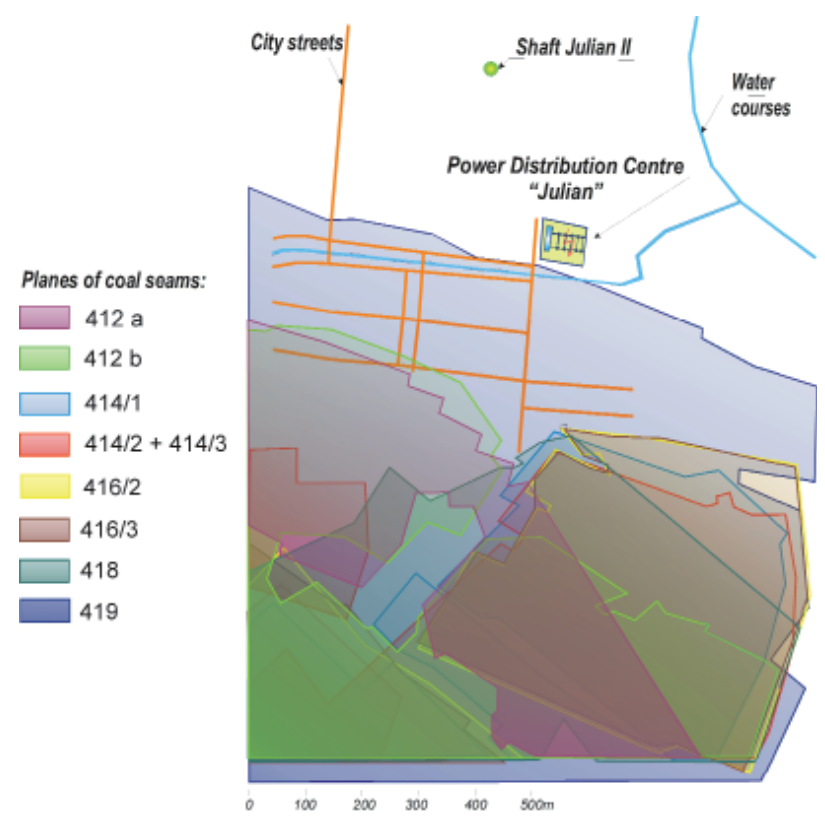

Fig. 6. Underground extraction layout of a group of " 400 " coal seams in the southern part of Piekary Slaskie.

operations at a small distance (or just below) from the PDC area were conducted using hydraulic backfill, which strongly reduces the subsidence effects. Caving systems were used in more distant mining operations and the subsidence troughs generated by these extractions could reach the PDC area only at their borders.

The answer to the question of subsidence sources at the PDC area was finally given by the geotechnical measurements conducted at the PDC site [14].

As a result of a series of boring, the geological profile of the area was made as well as geotechnical properties of the direct ground foundation of the PDC facility that have been determined.

Between other tests and calculations, a cone penetration test (CPT) was conducted. The direct measurement belongs to determining the number of hits of a special hammer required to drive a penetrating cone $0.2 \mathrm{~m}$ into the ground (N20). An example of the CPT test result for one of borings at the PDC area are shown in Fig. 7.

As can be seen from Fig. 7, the top soil layer of the ground is relatively strong as the N20 parameter ranged from 10 to 16 . However, at depths below $1 \mathrm{~m}$ down to about $5 \mathrm{~m}$, the grounds become very weak and the value of the N20 parameter is decreasing to a range of 1-6. Below $5 \mathrm{~m}$ the ground becomes more stiff, and limitations of our drilling equipment did not allow us to drill below $6 \mathrm{~m}$.

CPT measurements allow easy determination of numerous soil mechanics parameters important for ground stability analyses and design of foundations for building construction. Fig. 8 presents calculation of boundary ground resistance on the basis of averaged CPT test results from Fig. 7.

The main conclusion after field measurements at the PDC site is that the building of the PDC as well its overhead 


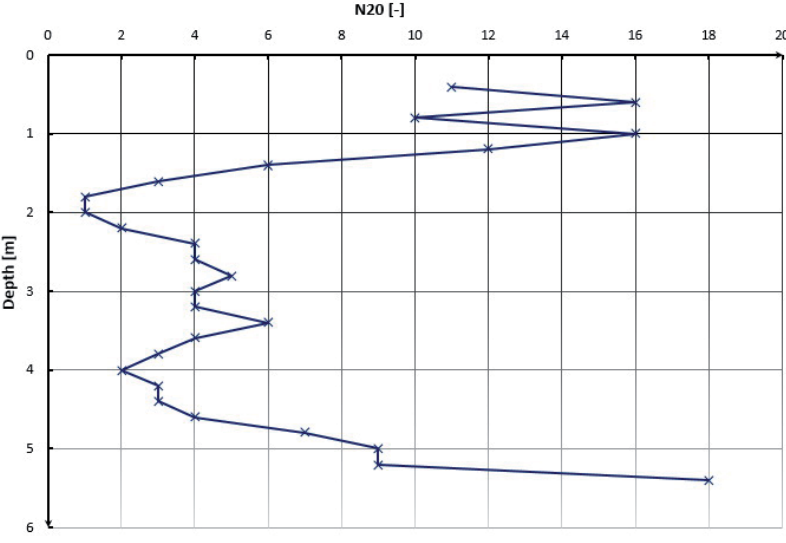

Fig. 7. CPT test results for borehole No. 3 at Julian PDC in Piekary Slaskie.

structures (transformers, switches, etc.) have been constructed on very weak ground, which in contemporary geotechnical nomenclature would be classified as uncontrolled heap or non-building ground [14].

The layer of that heap is between 3.2 and $5.0 \mathrm{~m}$ thick and consist of differentiated material, which suggests its anthropogenic origine. Its structure includes mixed sands, clays, clayey sands, gravels, aggregates, and - in large amounts - industrial waste, pieces of glass, concrete, wood, etc.

This ground has not been reinforced nor has any other geotechnical improvement been applied before construction of the PDC started. It is highly probable that the already weak structure of an old spoil heap or waste disposal place (as it is supposed to be due to the structure revealed by the borings) underwent further deterioration as a result of atmospheric precipitation, chemical erosion, suffusion processes, and more.

It cannot be excluded that ground movements related to mine subsidence could contribute to the disadvantageous processes at the PDC area; however, the main reasons of their occurrence was construction of such a facility on a totally inappropriate foundation after neither geotechnical preparations nor satisfactory construction provisions. However, it must be said clearly that at the time when the PDC was built there were no rules existed regarding geotechnical requirements for the foundations of structures.

\section{Case Study III: Subsidence and Seismic Activity Induced by the Recurring Flooding and Drainage of Undegorund Voids at Czeczott Mine}

Flooding an abandoned mine is a natural consequence of reconstruction of groundwater tables after closing down the drainage system. Its influence on the mining area surface movement was not the subject of larger interest; however, some research in that field can be found in worldwide literature.

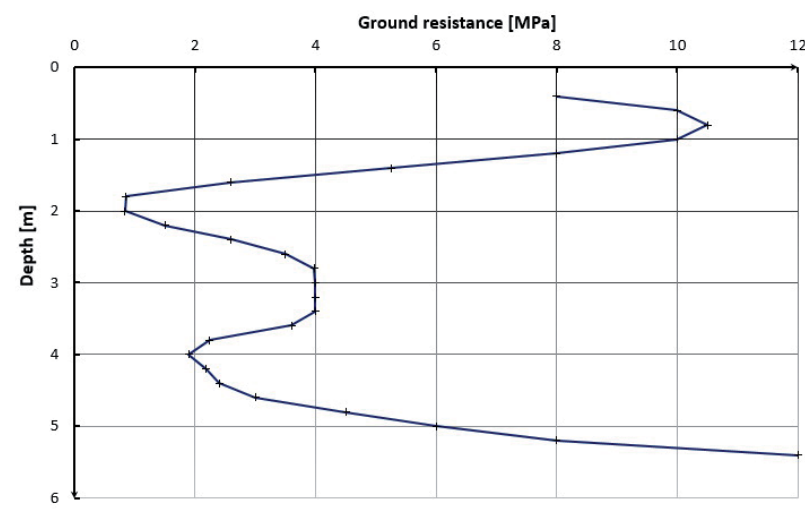

Fig. 8. Ground resistance calculated on the CPT test results for boring No. 3 at Julian PDC in Piekary Slaskie.

Flooding underground workings, caves, and other voids may result in elevation of the ground surface above underground water reservoirs, which occurs as a result of water level reconstruction [15].

The absolute value of magnitude of the ground lifting resulted from flooding an abandoned mine is much less than subsidence resulting from mining extraction operations. Nevertheless, ground deformations resulting from lifting processes may generate negative consequences for surface structures and objects, while protective measures in building construction on mine areas in the majority are not prepared for inverted stress-strain relations.

Flooding of underground mines may affect large areas of the surface in terms of ground surface elevation [16$18]$.

In USCB conditions, this problem became apparent when the Czeczott Coal Mine, which was decommissioned in 2008, was adopted as a retention reservoir for saline waters from other coal mines still operating nearby. The idea was to collect the saline waters from the drainage system of the mines during the periods of low water levels in the Vistula River, to avoid excessive increases of sulfate and chloride concentrations that result from the discharge of mine waters to a river. Waters from the retention reservoir would be discharged only during higher water level periods in this river, thus minimizing environmental impacts to the water courses and generating economic profits by avoiding environmental fees.

Czeczott is located in a rural area of the southern part of USCB. The extraction works were arranged to achieve optimal protection of villages located on the mining area, with most of the subsidence occurring in agricultural and forest areas (Fig. 9).

The volume of water that can be stored in the decommissioned mine was assessed as about 26 million $\mathrm{m}^{3}$. Mine workings, voids, and cavings between $650 \mathrm{~m}$ and $150 \mathrm{~m}$ below the surface was taken under consideration. Most of the storage volume will be destined for final disposal of saline mine waters from adjacent mines. By an inflow of 1.5-1.8 million $\mathrm{m}^{3}$ of water per year, the process of geological disposal of mine waters will significantly reduce the costs (as environmental fees) of water discharge 
for the next 13-16 years, depending on the level of natural inflows, which could be subject to change. The retention volume considered as capacity for temporary storage of water [19] is represented by voids between the depth of 150 and $300 \mathrm{~m}$ below the surface and is expected to ensure retaining of $500,000 \mathrm{~m}^{3}$ of water.

A vertical distance of $150 \mathrm{~m}$ between the maximal permissible water table and the ground surface has been established to avoid the possibility of mixing saline mine waters with shallow fresh water tables and to minimize influences of the water table movement on the surface of the ground.

Although the abandoned mine is neighboring active mine fields of other mines, the minimal distance between the drowned area and active mine workings reaches at least $135 \mathrm{~m}$. No water hazards from the side of the mine flooding is expected to appear in adjacent mines. Eventual negligible percolation should be addressed by the drainage systems of the respective mines.

Buoyancy force resulting from immersion of rocks in water generates stresses in the rock mass, which can lead to lifting up the rock mass. On the other hand, the concentration of stresses may lead to the generation of seismic events (shocks). This, however, depends especially on local geological conditions, which means especially the presence of stiff sandstone strata above fractured caving zones.

Results of numerical modeling of the abandoned Czeczott mine demonstrate that flooding process can generate seismic events (shocks) on the surface characterized by acceleration of maximally $65 \mathrm{~mm} / \mathrm{s}^{2}$ (Fig. 10) [19].

A precise survey of the mine area started after flooding of the mine shows that the subsidence processes are not yet complete. Relatively (to intensity of ground deformations

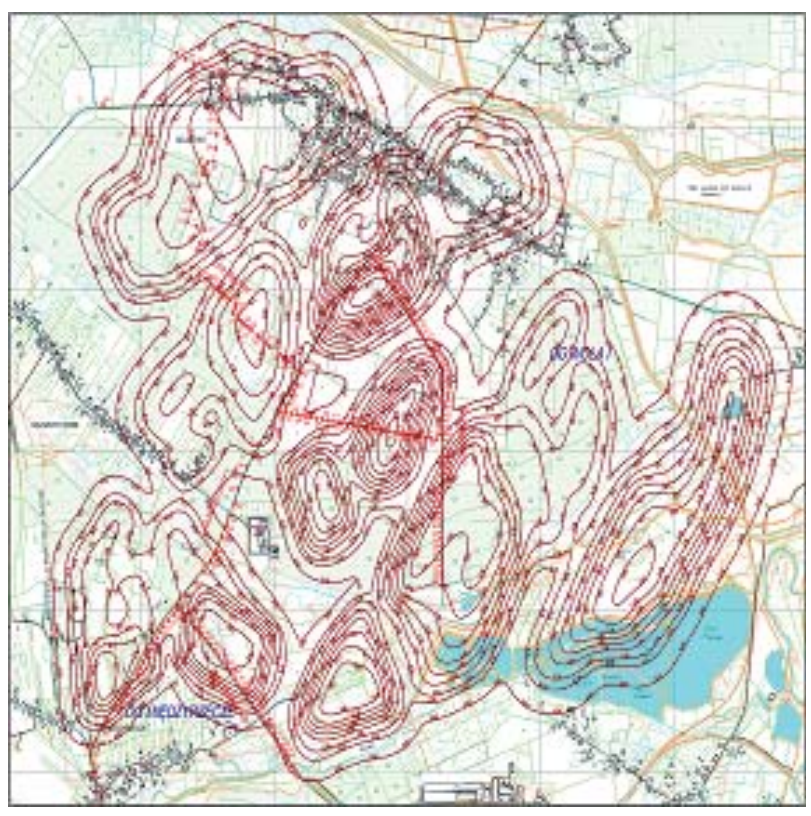

Fig. 9. Map of Czeczott mining area with surface protection categories for completed mining operations [19].

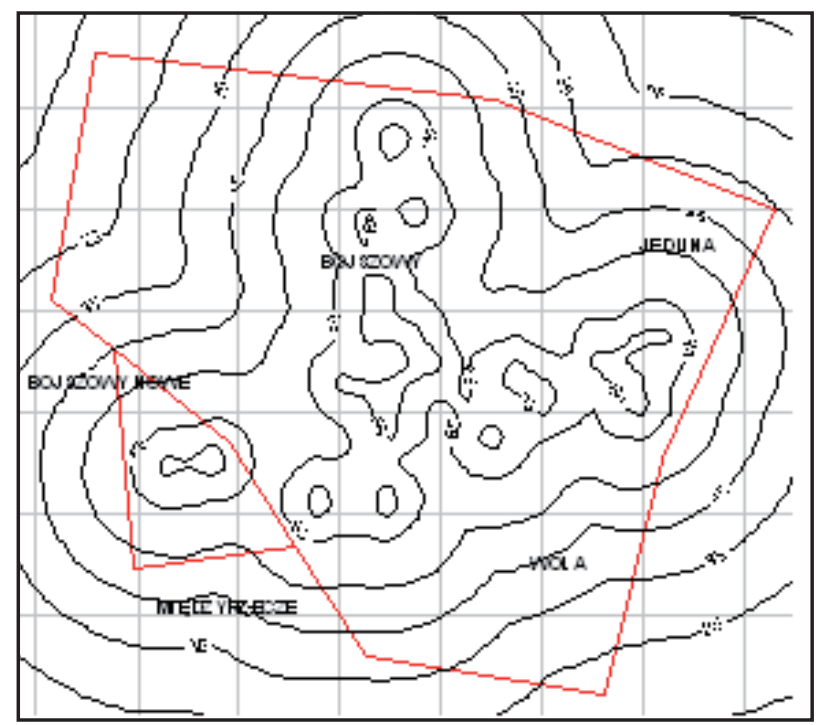

Fig. 10. Prognosis of maximal ground acceleration due to seismic events generated by flooding Czeczott mine [19].

during mining operations) small ground movements in both directions still occur, meaning sinking of ground surface as well as some lifting movements. Because the water level did not reach its maximal acceptable elevation until now, analyses are based on predictions and temporary measurements.

Generally it is expected that the final profile of the subsidence trough will be modified by the ground lifting related to flooding of the mine (Fig. 11) [19].

An example of an elevation prediction is presented in Fig. 12. As can be seen on the graph, the expected vertical displacement can reach maximally ca. $0.20 \mathrm{~m}$. Such a magnitude of ground-level movement can be potentially harmful for sensitive structures and buildings, as well as constructions partially protected against ground subsidence.

Cyclical mine flooding and discharging of waters to the Vistula creates complex conditions for ground surface

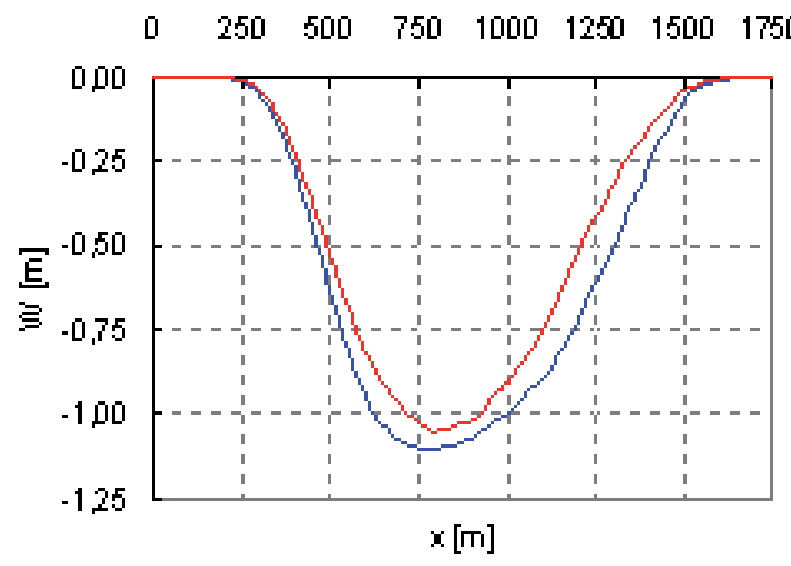

Fig. 11. Subsidence trough profile before (blue) and after mine flooding (red) [19]. 


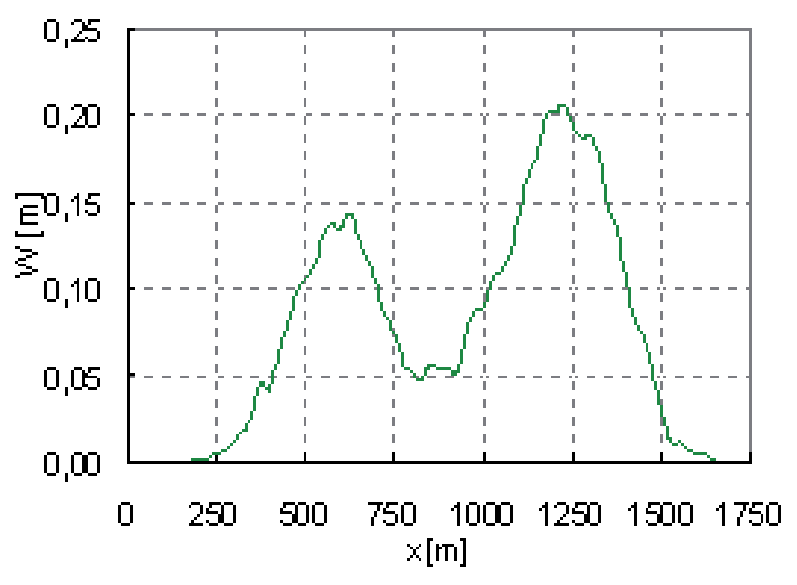

Fig. 12. Up-lift prediction after mine flooding [19].

stability due to recurring subsidence and elevation of the ground surface. The lifting movements during the phase of water discharge may be relatively intense, while the hydrological conditions of the Vistula allow discharge of salt waters only during relatively short time periods of high water levels, which occur ca. 1.5 months a year, while the storage capacity is $500,000 \mathrm{~m}^{3}$.

\section{Conclusions}

Mine subsidence and related geomechanical problems do not terminate as a mine ends its underground operations. The nature of processes occurring in the rock mass as a result of mine activities implicates phenomena that must be considered in a long-term perspective. Ground stability distortions on post-mining terrains may be observed during many decades (sometimes even centuries) after decommissioning a mine.

In presented case studies, the complexity of processes related to mining and post-mining effects occurring in the rock mass are hardly to be accurately described and predicted even with the use of advanced technologies and theoretical models, mainly due to the complexity of local geological and hydrogeological conditions.

In areas of intense industrial activities, and especially in mining industry regions, the amount of environmental impact and problems resulting from a heavily disturbed environment is so high that it will take many years after the last mine is decommissioned to return to balance. The problems mentioned in this paper are only a small part of the large list of different aspects of technical, economical, and environmental issues related to sustainable development of post-mining areas.

Sinkholes (discontinuous subsidence) and eliminating the risk of their appearance definitely belong to the most frequently observed problems in the USCB's post-mining areas. As has been shown in the discussed case studies, sinkholes impose real dangers to existing and prospective building construction, and their origination might not always be directly correlated with the most obvious activities. The reasons for unexpected ground movements and risks for building structures can often be referred to widely understood anthropogenic transformations of grounds. They include not only the most obvious results of present mining activities like induced seismicity and subsidence troughs, but also sinkholes from collapsing voids that remain after historical mining operations, dumping of rock masses, and waste or flooding of abandoned underground mines.

\section{Acknowledgements}

We gratefully acknowledge support of the project "Research on secondary rock mass movement and seismic vibrations of the surface of a mining area resulted from closure of an underground mine by its flooding" (N N524 464236) as granted by the Polish Ministry of Science and Higher Education.

\section{References}

1. JURECZKA J., KRIEGER W., WILK S. Prospective hard coal resources in Upper Silesian Coal Basin. [W] XIX Conference "Novelties and perspectives of mineral resources management" Mineral and Energy Economy Research Institute of the Polish Academy of Sciences, Krakow, 3, 2009.

2. STROZIK G. Filling of underground cavities in rock mass affected by mining operation. Silesian University of Technology Publishing, Gliwice, 4, 2015.

3. STRZAŁKOWSKI P. Prognosis of time lapse of final stage of mining ground movement after exploitation. Polish Mining Review, 4, 4, 2014.

4. STRZAŁKOWSKI P. Shallow cavities in mining areas in reference to sinkhole formation. Mining and Tunneling Construction, 21 (2), 5, 2015.

5. STRZAŁKOWSKI P. Outline of mining grounds protection. Silesian University of Technology Publishing, Gliwice 5, 2010.

6. KAWALEC J., GRYGIEREK M., CHLIPALSKI K. Communication line objects in mining areas. Motorways, 3, 6, 2015.

7. ZYCH J., MACHOWSKI M., TONDERA M. Results of A4 motorway monitoring in MOP Halemba and Wirek area. Work Safety and Environmental Protection in Mining, 6, 6, 2015.

8. JENDRUŚ R., STROZIK G., ZAJĄC J. Elimination of shallow, exploitation-caused cavities under building based on example of DK79 construction in Jaworzno. Sources for XIV International Symposium Geotechnika-Geotechnics, Gliwice - Ustroń 19-22 october, 6, 2010.

9. JENDRUŚ R., STROZIK G. Problem of ground cavities detection under buildings based on measurements and decommissioning works. Science Conference Mining of diversified development, Silesian University of Technology; 7, 2011.

10. PLEWA F., POPCZYK M., PIERZYNA P., ZAJĄC A. Use of materials with energetic waste content for elimination of sinkholes caused by mining operation. Polityka Energetyczna, 14 (2), 7, 2011.

11. DODD W.E. Structural Monitoring at a Pressurized Grout Remote Backfilling AMLR Project at Beulah, North Dakota. National Association of Abandoned Mine Land Programs Annual Conference, August 19-22; Athens, Ohio, USA; X, 7, 2001. 
12. KUBAŃSKI A. Terrain remediation technologies for construction Modern Engineering Construction, 4 (19), 68, (page 7) 2008.

13. Erzkarte des Oberschlesischen Erzbergbaus, sheet No. 16 Scharley, printed by Obergberamt in Breslau, Germany; (8, Fig. 5), 1913.

14. JENDRUŚ R., STROZIK G. Made ground as a source of discontinuous deformations and geotechnical hazards to buildings, based on example of electrical substation "Julian" in Piekary Slaskie. Science Conference Mining of diversified development, Silesian University of Technology; 8, 2012.

15. BUKOWSKI P. Prognosis of water hazard caused by flooding of coal mining operation sites. Scientific Papers of Central Mining Institute, Katowice, 882, 11, 2010.
16. FENK J. Eine analytische Lösung zur Berechnung von Hebung der Tagesoberfläche bei Flutung unterirdischer Bergwerksanlage. Das Markscheidewesen 107 (2), 11, 2000.

17. HEITFELD M., ROSNER P., MüHLENKAMP M., SAHL H. Bergschäden im Erkelenzer Steinkohlenrevier. 4. Altbergbau-Kolloquium Leoben; 11, 2004.

18. PöTTGENS J.J.E. Bodenhebung durch ansteigendes Grubenwasser. 6. International Congress of Mine Survey, Harrogate; 11, 1985.

19. PALARSKI J. et. al. Final report from the project N N524 464236: Research on secondary movement of rock mass and vibrations of mining area surface, caused by decommissioning of coal mine by flooding. (Unpublished results) Silesian University of Technology, Gliwice; 11, 2012. 
